\section{特集 子供と大人 \\ の心身症}

順天堂医学 38 (4)

P. $485 \sim 491$ (1993)

\section{消化器領域における心身症**}

\section{Psychosomatic disorder in digestive system}

\author{
荻原達雄*1) 佐 藤信紘*2) \\ Tatsuo OGIHARA, M. D. \& Nobuhiro SATO, M. D.
}

消化器領域には心身症としての取り扱いが必要な疾患が多い. 消化器各臓器が心理的・精神 的因子の影響を受けやすいのは, 自律神経系や内分泌系を介して中枢神経系と密接に関連して いるためである.

本稿では, 消化器領域での代表的な心身症として, 消化性潰瘍・急性胃粘膜病変・過敏性腸 症候群について症例を紹介し, 病因についての消化管粘膜血流や消化管運動の面からの研究の 一端を紹介した。

特に消化管粘膜血流は粘膜細胞機能を維持する重要な役割をもっており, 血流障害は病変発 生と密接に関連している.胃においては, 潰瘍などの病変の発症に, 粘膜血流の低下をはじめ とする粘膜防御機構の破綻が関与するてとが明らかにされている. ストレスなどの全身性因子 によって粘液・粘膜血流等の粘膜防御系の減弱がもたらされるてとも証明されており, 精神的・ 心理的因子による病変発生の機序の一つと考えられる. 過敏性腸症候群などの消化管運動機能 異常を呈する疾患についても, 粘膜微小循環への影響が認められており, 粘膜細胞機能障害を ともなっている可能性がある.

キーワード：消化管粘膜血流, 消化管運動, 消化性潰瘍, 急性胃粘膜病変, 過敏性腸症候群

Key words : gastrointestinal mucosal blood flow, gastrointestinal motility, peptic ulcer, acute gastric mucosal lesion, irritable bowel syndrome

\section{はじめに}

心身症 psychosomatic disorder (PSD) は, 「身体症状を主とするが, その診断や治療に, 心理 的因子についての配慮がとくに重要な意味をもつ 病態」（日本心身医学会：1970）と定義されてい るが, 現在では, 心理的・精神的原因が主たる発 症要因となった疾患のほかに，身体的原因によっ て発症した疾患であっても，その経過に心理社会

* 順天堂大学医学部内科学教室消化器内科

*1) 助手 *2) 教授

Department of Gastroenterology, Juntendo

Uniwersity, School of Medicine, Tokyo, Japan

**第262回順天堂医学会学術集会 (Sept. 17, 1992 開催)

[Oct. 28, 1992 原稿受領]
的因子が重要な役割を演じているものも心身症と して取り扱うことになっている.消化器領域にお ける心身症としては, 表-1のように多くのものが あげられる.乙のうち, 過敏性腸症候群などは心 理的要因か溌症に強く関与しており, 一方, 潰瘍 性大腸炎などは症状の経過に心理的因子が影響を 与える. すなわち, 潰瘍性大腸炎の発症には免疫学 的機序が考えられているが, 精神的ストレスがしば しば本症の再燃・増悪を招くことか知られている。

心身症としての消化器疾患には, 表-1亿あげた もののほかに, 背景に飲酒癖の問題を有すること から心身症としての対処が必要なアルコール性肝 疾患なども含まれる。

心身症における症状は特定の器官に固定化して 出現する傾向があり, 通常その基盤に病態生理学 
表- 1 心身症としての消化器疾患

\begin{tabular}{l}
\hline 食道神経症 \\
神経性嘔吐症 \\
急性胃粘膜病変 (AGML) \\
消化性胃・十二指腸潰瘍 \\
non-ulcer dyspepsia（NUD) \\
空気嬹下症 \\
過敏性腸症候群 (IBS) \\
潰痬性大腸炎 \\
胆道ジスキネジ- \\
慢性膵炎 \\
神経性食欲不振症 \\
\hline
\end{tabular}

的な機能障害や器質的障害が認められる.たとえ ば胃潰瘍や十二指腸潰瘍などの消化性潰瘍の場合, 潰瘍の発症に, 粘膜血流などの粘膜防御機構の破 綻が存在することが証明されており ${ }^{12 ! ， ス ト レ ~}$ スなどによって潰瘍再発を繰り返す，いわゆる 〈潰瘍症>の人においても, ストレス負荷により 粘膜防御系の減弱が生じやすい状態にあると考え られる.

本稿では, 消化器領域における代表的な心身症 として, 消化性潰瘍・急性胃粘膜病変・過敏性腸 症候群をとりあげ，その症例を提示するとともに， 病因についての研究の一端を紹介した。これらの 疾患はいずれも日常臨床の場でしばしば遭遇する 疾患であり, 精神的因子の関与について, 自律神 経系や内分泌系など様々な面から検討がなされて いる.

\section{消化性潰瘍}

症例 : 45歳男性 会社員

2 力月前に職場が変わり, その頃から空腹時に 上腹部の痛みを生じるようになった，市販の胃薬 を服用したが症状は改善せず，夜間の不眠・起床 時の嘔気なども出現するようになったため, 当院 を受診した。

本患者に施行した内視鏡検査で，胃角部小变に 径 $1.5 \mathrm{~cm}$ の深い潰瘍を認めた．潰瘍底には凝血塊 が付着しており活動期の潰瘍であった。

胃潰瘍の発症や再発に何が誘因となったかを調
べた報告 ${ }^{\prime}$ 亿よると，誘因として多かったものか ら順に，仕事が忙しかったもの51\%，規則正しい 食事ができなかったもの $42 \%$, 寝不足が続いたも の $37 \%$, 収入の減少 $25 \%$ な゙があげられている。 この報告からもわかるように胃潰瘍の発症・再発 には，日常生活における精神的・肉体的ストレス が原因となることが多い.

小児の場合には，家庭内の心配事や試験のスト レスなどがいちじるしい場合に，出血性の潰瘍を 発症することがある.てのような患者に対しては， 原因となった精神的ストレスの除去が潰瘍治癒に とってきわめて重要である.

心身症としての消化性潰瘍の特徵として, (1)潰瘍病変の発症と経過に心的なストレスが関与 している.

(2)再発することが多い.

(3)潰瘍性格といわれる性格傾向をもつ. などがあげられている4!

ここで潰瘍性格とは，良心的すぎる・強迫的・ 凝り性・野心的・頑固・勤勉などを指す.

消化性潰瘍患者の特徵として他にも, 喫煙の継 続や服薬が不規則となりがちなととなどの不適切 な保健行動がみられる.また, うつ病と合併して 発症している場合もみられる。

\section{急性胃粘膜病変 $(A G M L)$}

症例：30歳男性 会社員

生来健康であったが, 徹夜で麻雀をした翌朝に 嘔気・嘔吐を生じ, 吐物に血液が混じっていたた め当院を受診した，麻雀中は食事を摂っておらず, タバコを約40本吸った。

来院時の内視鏡検查では，胃体部を中心に出血 性びらんの多発がみられ, 急性胃粘膜病変 (acute gastric mucosal lesions; AGML) と診断した.

本例では, 徹夜麻雀という精神的かつ肉体的ス卜 レスが胃病変の発生をもたらしたことは明らかであ る. また，喫煙も粘膜血流を始めとする胃粘膜防御 機構を著明に低下させることが分っており ${ }^{51}$, 本患 者における病変の発生の一因となっている. 
本患者に対しては入院安静および $\mathrm{H}_{2}$ ブロッカー 等の薬物療法を行った結果, 2 週後の内視鏡検査 では, 病変がまったく消失し正常粘膜となってい た. 誘因が除去されると, 病変そのものが比較的 短時間で消失することが急性胃粘膜病変の特徵で ある(表- 2 ).

急性胃粘膜病変は一つの疾患概念であり,「突 発する胃症状を伴い, X線・内視鏡検査により胃 粘膜に異常所見を認める病変」と定義されてい $ろ^{6}$. 胃病変としては, 急性胃炎・急性胃潰瘍・ 急性胃びらんが含まれ, てれらを一つの症候群と みなすととが, 治療等の臨床的立場から合理的で あると考えられた。

急性胃炎や急性胃びらんは, 消炎鎮痛剂などの 外因性またはストレスなどの内因性の刺激によっ て急激に発症し, 上腹部痛・上腹部膨満感・悪心・ 嘔吐等の胃症状が出現する. 吐血・下血を伴うこ ともまれではない.

急性胃粘膜病変の診断は, 発症時の迅速な内視 鏡検査によって正確に下されるようになった。内 視鏡下肉眼所見としては, 胃体部を中心とした広 範な粘膜面の線状・点状の多発びらん・発赤・浮 腫などの多彩な変化が認められ, びまん性の出血 を伴うことも多い. 胃X線においても, 粘膜面の びらん・浮腫・粘液過唾などの所見がみられ, 症 状の極期には幽門狭窄や排出異常などのX線像を 呈することがある.

急性胃粘膜病変の発生機序については, 胃粘膜 防御能低下と攻撃因子側の両方の役割が詳しく調 べられている. 胃粘膜に対して外因性に化学的・ 物理的刺激が加わると, 粘液・粘膜血流等の粘膜 防御機構の減弱がもたらされ, 胃酸が増悪因子と して作用して粘膜病変が発生すると考えられる ${ }^{7 !}$. 同様にストレスや全身性疾患に起因する胃病変に 関しても, 粘液・粘膜血流等の粘膜防御機構の減 弱がもたらされることが粘膜病変発生の引き金に なることが明らかになっている。

ストレスなどの全身性要因による胃粘膜防御の 障害機序として, 従来から, 中枢性の交感神経刺 激作用・副交感神経刺激作用・ホルモン分泌刺
表- 2 急性胃粘膜病変 (AGML) の特徵

a. 出血性びらんが, 胃体部をはじめ胃内の広い範囲に 多発する。

乙の変化は通常 1 週間以内に消失する.

b. 浅い急性の潰瘍が多発し, 症例によっては出血を伴 うことがある.

この変化は通常 $2 \sim 3$ 週で消失する.

c. びまん性の粘膜出血だけがみられるもので, 多くの 場合 $1 \sim 2$ 日位で出血所見が消失する.

激作用の各系統の総合的作用が考えられてきた ${ }^{8)}$. ストレスによる交感神経の興奮は胃粘膜の血流を 低下させ, 粘膜虚血による障害を惹起する. 一方, ストレスによる副交感神経中枢への刺激は, 迷走 神経を介して胃酸分泌の増加および, 胃運動の六 進をもたらし粘膜病変を増悪させる因子となる.

さらに, ストレス刺激による副腎皮質ホルモンの 分泌は, 胃酸・ペプシン分泌充進, 胃粘液の低下 をもたらし，いずれも粘膜病変を増悪させる要因 となる ${ }^{9}$.

特に胃粘膜血流の障害は, 病変の発生に重要な 役割を持つと考えられる ${ }^{10)}$. 消化管粘膜血流は粘 膜細胞の機能維持にとって根底で支えている防御 機構の重要な因子である ${ }^{11)}$ (表- 3 ). 粘膜毛細血 管が虚血やうっ血の状態になると, 粘膜細胞への 酸素供給が傷害され, 粘膜低抗を減弱させて粘膜 病変の発生をもたらす(図-1).

血流低下状態が病変発生に密接に結び付いてい ることは, 臨床における血流測定によっても確認 されており, 著者らは内視鏡下に臓器反射スペク トル法を用いて消化管粘膜血行動態の検討を行っ てきた ${ }^{12)}$. 臓器反射スペクトル法は, 内視鏡鉗子 孔から挿入した光ファイバーを通して, 白色光を 粘膜面や臟器表面に照射し, 得られた散乱反射光 を高速にスペクトル解析して, 非侵襲的に局所の 血液量や酸素化の指標を得る方法である ${ }^{13)}$.

急性胃粘膜病変発症に対する胃粘膜血行動態の 解析を行った例を紹介する. 重度外傷などの全身 的ストレス状態にある患者が出血性潰瘍などの重 篤な急性胃粘膜病変を発症するととが知られてお り, 胃粘膜防御機構の減弱状態が存在すると考え 
表- 3 粘膜血流の役割

1.酸素, エネルギー基質の供給

2、ホルモン, 生理活性物質の供給，代謝調節作用 細 胞増殖, 分化調節機能

3. 老廃物, $\mathrm{H}^{+}$イオンの処理, 運搬

4. 重炭酸イオンの運搬, 分泌

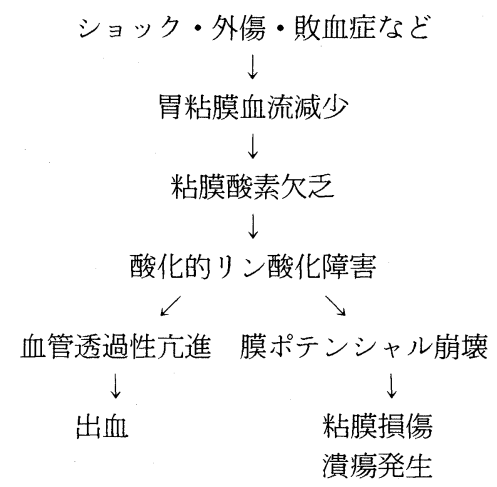

図-1 ストレス潰瘍の発生機序

られる. そこで, 救急入院した重度外傷・熱傷患 者について内視鏡を施行した際に, 藏器反射スペ クトル法により胃粘膜血液量指標を測定した結 果 ${ }^{14)}$, 図- 2 亿示すごとく，後に急性胃粘膜病変を 生じた右端のグループでは, 正常者群および胃粘 膜病変を発症しなかった外傷患者のグループに比 べ, retrospective にみた病変発生前の胃粘膜血 液量に有意の低下が存在していた。

近年は，ストレス等の全身性の要因による胃粘 膜血流傷害に粘膜局所において関与する因子とし て，ロイコトリエン（LT）や血小板活性化因子 (RAF) などの炎症性メディエイターが注目され ている ${ }^{15)}$. 消化管粘膜に豊富に含まれる肥満細胞 は乙れらのケミカルメディエイターの産生源であ り, 免疫機構とも密接に結び付いた因子である.

図-3は乙れらのケミカルメディエイターを介した 胃粘膜病変発生機序をシェーマ的に示したもので, ストレスによる全身的要因によって, 従来より知ら れた自律神経を介した血管系への作用に加え, 粘 膜局所におけるLTPPAF の放出により, 血管透 過性の艺進や血小板凝集等による粘膜表層の

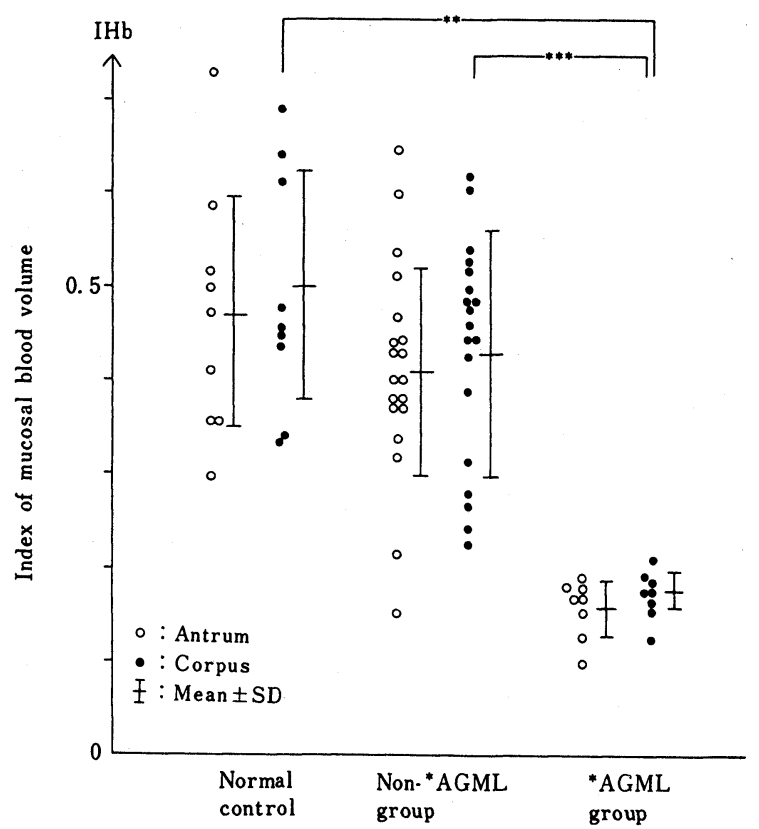

(9)

(19)

(8)

* AGML: Acute gastric mucosal lesion **: $p<0.01$, compared to the value of control group ***: $p<0.001$, compared to the value of non-AGML group

図- 2 救急入院した熱傷または頭部外傷患者の胃粘膜 血液量 ${ }^{14}$

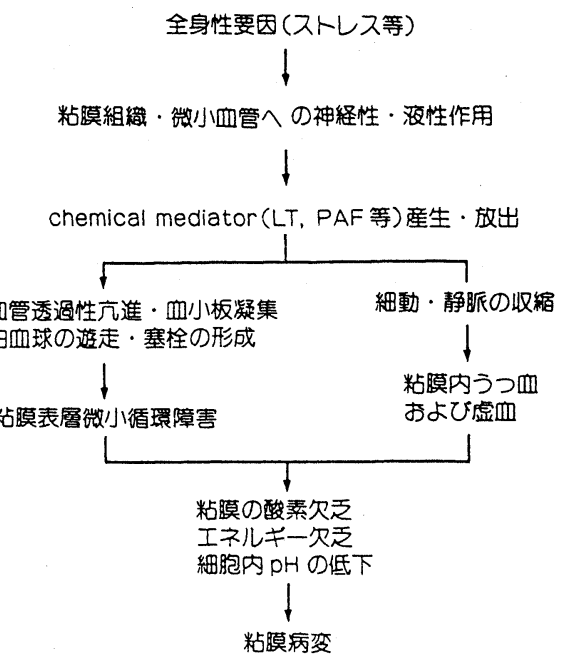

図-3 ケミカルメディエーターを介した消化管粘膜病 変の発生機序 
循環傷害がもたらされ, 細動脈・細静脈の収縮に よる粘膜のうっ血や虚血を生じて粘膜病変を発生 させると考えられる.

\section{過敏性腸症候群}

症例 : 21 歳男性 大学生

高校生の時は, 便秘が数日続くとその後は下㢉 になることの繰り返しに悩まされていた。

大学に入学した年は症状が抒さまっていたが, 2 年目頃から毎日数回の腹痛・下㾝を生じるよう になり, 特に試験シーズンには 1 日に10回近くの 下㢉を生じた。

食欲が低下したり体重が減るということはなかっ たが，通学途中でも便意ががまんできなくなって トイレに駆け込むほどの状態になったため, 当院 を受診した。

[検查所見］

一般血液検查 : 異常なし. 血沈・CRP 等の炎 症反応も陰性.

検便 : 便潜血反応陰性. 細菌培養 : 病原菌 $(-)$.

注腸X線検查 : 腸管が spastic であるほかは特 に異常なし。

大腸内視鏡検査 : 粘膜面は正常で,びらん・発 赤等の所見なし.

本症例では, 炎症性腸疾患に特徵的な血便等の 症状がないことや, 諸検查で器質的病変が見いだ せなかったことより, 過敏性腸症候群（irritable bowel syndrome; IBS) と診断した.

本例のように, 若年者で頻回の下痢があり精神 的ストレスで症状が増悪する場合, 過敏性腸症候 群が最も考えられるが，他に潰瘍性大腸炎などの 疾患が存在しないことを確認しておく必要がある。

本症は，神経質な性格等を背景にもつ患者にみ られる代表的な消化器心身症の一つで, 腸管機能 の六進による下峲や痙攣性便秘などの便通異常を 主症状とする。しばしば下痢と便秘とが数日間の 間隔で交代して生じることも本症の特徵である. 以前は過敏性大腸炎と称されていたが，大腸以外 に，小腸を含め腸管全体の機能異常を伴うことが
表- 4 消化運動機能異常のみられる消化器疾患

食道: 逆流性食道炎 アカラシア

胃：non-ulcer dyspepsia 胃潰瘍 慢性萎縮性胃 炎 AGML

大腸：過敏性腸症候群 虚血性腸炎 大腸咊室症 潰瘍 性大腸炎

明らかとなったととから, 過敏性腸症候群と称す ることになった。

過敏性腸症候群は, 動悸・不眠などの自律神経 症状・精神症状を伴うことが多く, 治療にあたっ ても, 患者の不安を除去し心理的な安定を取り戻 させることが重要である. 心身症としての理解の 上にたって, 病態の十分な説明を行うことが症状 の改善に役立つ. また, 薬物療法としての精神安 定剂や腸管の運動機能改善剤の投与も有効である ことが多い.

過敏性腸症候群は, 腹部不定愁訴を主症状とす る non-ulcer dyspepsia（NUD）とともに, 症状 の出現・増悪が消化管運動異常と関連する代表的 疾患でもある（表-4）. 消化管運動異常を伴う疾 患と, 心身症として取り扱われる疾患にある程度 の重なりがみられるのは, 消化管運動自体が中枢 神経系の強い影響を受けているためである ${ }^{16) 177 .}$

蠕動などの消化管運動の六進や低下は粘膜血流 にも影響すると考えられ, 疾患によっては粘膜血 流障害を介した病変発生が想定される。過敏性腸 症候群は, 本態は腸管平滑筋の協調運動不全であ るが, 下痢や粘液排泄などの症状出現には, 腸管 粘膜細胞の機能不全も伴っている可能性が考えら れる.したがって, 腸管運動異常についても, 細 胞の維持調節を担う粘膜微小循環レベルでの解析 が行われている18)。

大腸内視鏡下に臟器反射スペクトル法の測定用 プローブ先端を, 大腸粘膜に連続的に接触させて 得られた粘膜血行動態の経時的変化の例を図- $4 \mathrm{a}$, bに示す. 各図とも上段のグラフは大腸粘膜血液 量の経時的変動, 下段のグラフは粘膜酸素化度の 変動を表す. 健常者（図-4a）に比べ, 過敏性腸 症候群患者（図-4b）では, 粘膜血液量指標・粘 


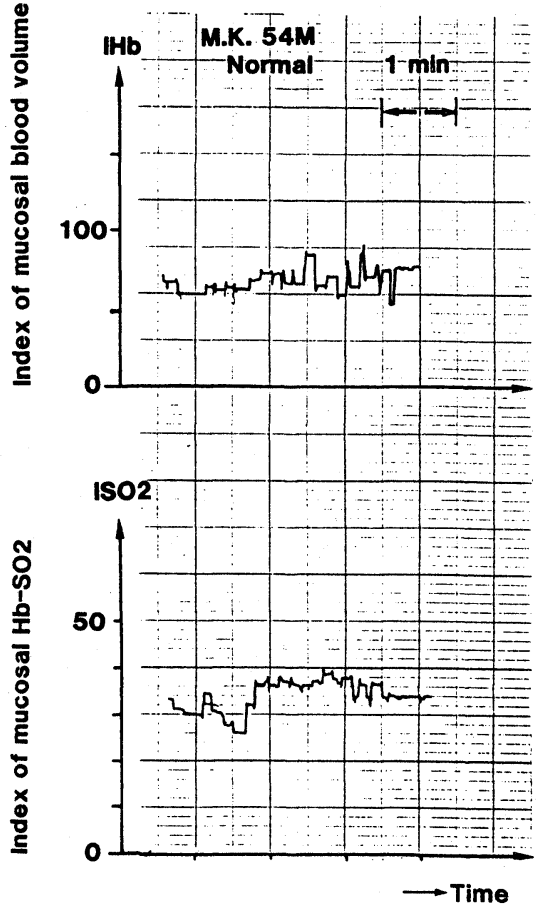

図-4a 健常人（非過敏性腸症候群）の大腸粘膜血行動 態の経時的変動

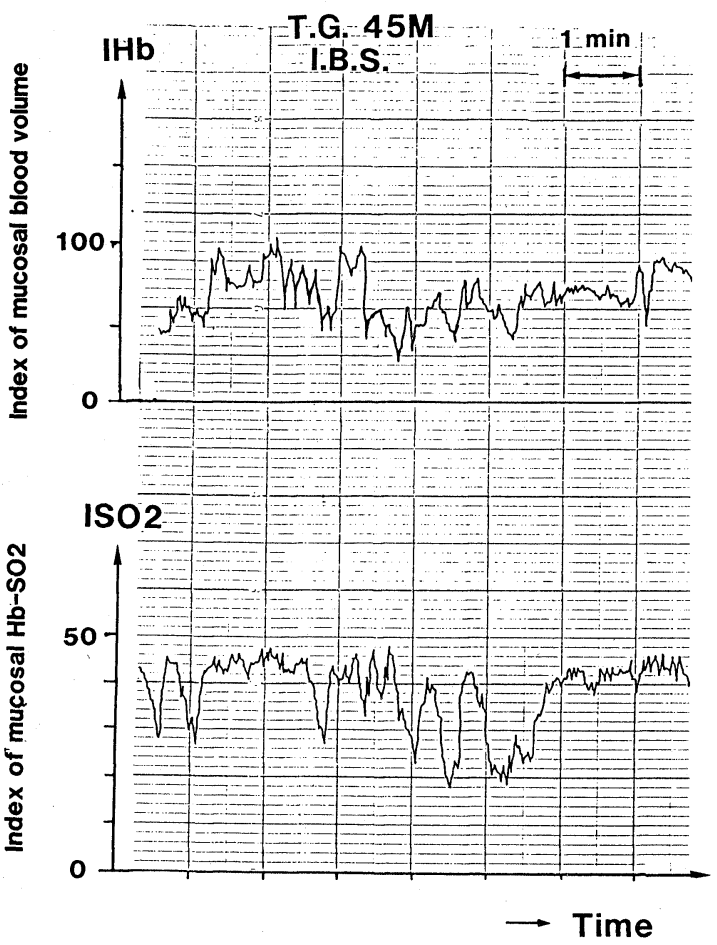

図- $4 \mathrm{~b}$ 過敏性腸症候群患者の大腸粘膜血行動態の経時 的変動
膜酸素化度指標の変動が大であり, 両指標の低下 時には一過性の粘膜虚血状態が生じていることが わかる.すなわち, 腸管機能異常においては腸管 粘膜微小循環力湾動しやすく, 粘膜細胞機能維持 への障害となっている可能性を示している.

$$
\text { まとめ }
$$

消化器領域においては心身症としての取り扱い が必要な疾患が多く知られている。消化器臟器が 心理的・精神的因子の影響を受けやすいのは，中 枢神経系との密接な関連が存在しているためであ る。乙れまで自律神経系, 脳・腸ホルモン, さら に近年では, 精神神経活動が免疫系に与える影響 など様々な観点から, 精神活動をになう高次神経 系と消化器各臟器との相関について注目されてき た。

本稿では, 消化器領域における代表的心身症と して, 消化性潰瘍 - 急性胃粘膜病変 - 過敏性腸症 についての症例を提示し, 消化管粘膜血流や消化 管運動の面からの病因との関連についてその一端 を紹介した。

今後, 社会的にストレスの増加が予想され，乙 れに伴って心身症としての対処が必要な疾患がま すます重要になっていくものと思われる.

\section{文献}

1) 荻原達雄, 佐藤信紘, 川野 淳, 他 : 粘膜血行動態 からみた胃・十二指腸潰瘍の病態と治療。機能面から みた胃・十二指腸潰瘍の病態と治療, 竜田正春, 他編, 裕文社, 東京, $25 \sim 43,1989$

2 ）佐藤信紘, 荻原達雄, 三輪洋人, 他：消化性潰瘍の 発症機序をめぐるトピックス. 内科, 69 : 412〜416, 1992

3）川上 澄, 馬場滝夫, 斉藤 博, 他: 心身医学から みた消化性潰瘍．内科，63：438～443，1989

4 ) 河野友信 : 心身症としての消化性潰瘍. COMMON DISEASE SERIES 消化性潰痬, 松尾 裕編, 南江堂, 東京, 273 277, 1991

5 ) Kawano S., Sato N., Tsuji S. et al.: Effect 
of cigarette smoking on the gastric mucosal blood volume index and hemoglobin oxygenation in man. Gastroenterologia Japonica, 24 : $1 \sim 7,1989$

6 ) 川井啓市, 他 : 急性胃病変の臨床一胃出血の面か ら. 胃之腸, $8: 17 \sim 23,1973$

7 ) 佐藤信紘, 荻原達雄, 辻 晋吾 : 外因性急性胃炎一 病態生理を中心に. Pharma Medica, 6 : 19 22, 1988

8 ) 並木正義 : ストレス潰瘍の概念と問題点. ストレス 潰瘍, 並木正義編, 新興医学出版社, 東京, $1 \sim 8$, 1978

9 ) 伊藤和郎, 松尾 裕：ストレスと胃. 消化器科, 12 : $628 \sim 636,1990$

10) Sato, N., Kawano, S., Kamada, T. et al.: Hemodynamics of the gastric mucosa and gastric ulceration in rats and in patients with gastric ulcer. Dig. Dis. Sci, $31: 35 \mathrm{~s} \sim 41 \mathrm{~s}, 1986$

11）佐藤信紘, 荻原達雄: 上部消化管微小循環。最新医 学, $46: 1820 \sim 1828,1991$

12）荻原達雄, 佐藤信紘 : オプトエレクトロニクスの医
学・臨床への応用. 病態生理, $11: 284 \sim 289,1992$

13) Sato, N., Kamada, T., Shichiri, M. et al.: Measurement of hemoperfusion and oxygen sufficiency in gastric mucosa in vivo, Gastroenterology, $76: 814 \sim 819,1979$

14) Kamada, T., Sato, N., Kawano, S. et al.: Gastric mucosal hemodynamics after thermal or head injury. Gastroenterology, 83:535 540,1982

15）荻原達雄, 佐藤信紘：Chemical mediator と胃 粘膜障害. 消化性潰瘍一臨床と基礎, $10: 225 \sim 231$, 1991

16）佐々木大輔, 岩根 敏, 屠 聿揚 : ストレスと腸疾 患. 消化器科, $12: 637 \sim 643,1990$

17）吉田 豊, 佐々木大輔 : 過敏性腸症候群の病態. 臨 床消化器内科, $4: 235 \sim 243,1989$

18) Tsujii M., Kawano S., Ogihara T., et al.: Mucosal microcirculatory disturbances caused by accelerated peristalsis. Gastroenterology, 100 : A 502, 1991

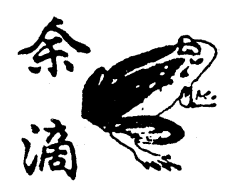

日本の現代医学と医療の本格的な進歩はやっと昭和 30 年 $(1955)$ 頃からであり，30数年後の現在まだ分ら ないてと，できないてとばかりである。しかも医療機 器と医師の能力によって医療に限界があるてとは明ら かである.

入院患者の点滴は漏れてはいけない，意識のほけた 患者もベッドから落ちてはいけないし, 雨の中にさま よい出てはならない.いかなる患者も縛りつけてはい けない，極めて少数の疾患以外は後遺症をの乙さず, 全治させなければならない. なぜならば，治してもら うために入院したのであるからと．

最近，ある院長の会合で，かぜを引いたと思うとい う中年女性が㴆宅後, くも膜下出血で死亡し, 訴訟し た。同じく更年期障害かと受診した中年婦人か締宅後, くも膜下出血で死亡し, 訴訟したと. 新聞紙上ではワ クチンで後遺症をのてした患児群が訴訟しており,
癌患者に MRAS の感染があったとして, 訴訟したと いう.

ベらべら喋って歩いて帰った患者があとで頭蓋内出 血で死亡するてとを一回の診察で予見できるであろう か. ある小児がワクチンで障害をのてすてとが，予め 分るはずがない．ましてや外来患者や入院患者の数十 パーセントが持っている MRSA を癌の末期患者力持っ ていたからといって，それが直接の死因であると，ど うやって決めるてとができるであろうか.

米国の Duke 大学では1990年春までに134人の HIV 陽性患児があり，111人が周産期感染で，母親の多く はコカインの静注で感染したらしいという（Dediatrics, 1992, 90-1, p.174).乙れがまた，医療事故の原 因となる日も遠くあるまいと思う。なぜならば，患者 のプライバシ一, 人権を重んじ, 病院内にも陽性者が 働くようになるであろうから．恐ろしいことである. 国際親善病院院長 加藤 英夫 